\title{
Lipidomics in biomarker development
}

\author{
Markus Wenk \\ From Immunodiagnosis of Tuberculosis: New Questions, New Tools \\ Virginia, VA, USA. 21-23 September 2008
}

Research into the cell biology of intracellular pathogens has provided information on host-pathogen interactions and on the importance of lipids at various stages in the interactions. Lipids are "gatekeepers" in important chemical reactions involving cell signaling during pathogen docking, invasion and traffic in and out of cells. Working with the Novartis Institute for Tropical Diseases, our team is exploring how TB takes advantage of normal cellular processes by using its own lipids to subvert the host's lipid signaling - allowing it to enter the host cell and survive there. Our focus is on developing host and pathogen biomarkers that correlate with TB infection in laboratory animals and in humans. We are performing mass spectrometry-based multi-marker quantification of lipids in tissue and body fluids (blood, urine, sputum), specifically host lipids (e.g. phospholipids and ceramides) and pathogen-derived lipids (e.g. mycolates, LAM, etc.). Our research is focused on laboratory animals and TB patients in clinical trials, to be used both for drug efficacy studies as well as case detection and monitoring of treatment response. For analysis of the host response, lipids are extracted from infected tissues and cells, isolated and analyzed by mass spectrometry to develop a lipid profile, which is used to identify the metabolic pathways involved in the infection and the enzyme/protein that facilitates the process. This technique is very sensitive - a drop of blood is potentially enough to perform the analysis. For pathogen biomarker discovery, mycobacterial lipids are isolated directly from small volumes of infected body fluids such as sputum and subsequently quantified via mass spectrometry. We expect this research will be (i) useful in

Correspondence: bchmrw@nus.edu.sg

Department of Biochemistry and Department of Biological Sciences, National University of Singapore, 117597, Singapore providing a better description of mycobacterial biosynthetic activity, which will be helpful in developing new diagnostics, drugs and vaccines, and (ii) for the development of lipid biomarker for TB case detection.

Published: 17 December 2010

doi:10.1186/1753-6561-4-S3-O3

Cite this article as: Wenk: Lipidomics in biomarker development. BMC Proceedings 2010 4(Suppl 3):O3.
Submit your next manuscript to BioMed Central and take full advantage of:

- Convenient online submission

- Thorough peer review

- No space constraints or color figure charges

- Immediate publication on acceptance

- Inclusion in PubMed, CAS, Scopus and Google Scholar

- Research which is freely available for redistribution

Submit your manuscript at www.biomedcentral.com/submit
Ciomed Central 